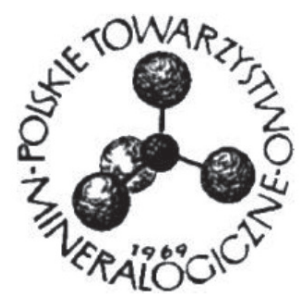

\title{
Simple steps for the detection and classification of different lamprophyric rocks: a case study from Greece
}

\author{
loannis-Nektarios G. Kamvisis ${ }^{1 *}$, \\ Elena A. Vasyukova² \\ ${ }^{1}$ Consultant Geologist's office, Greek Ministry of \\ Defence, 227 Mesogion av., Athens, Greece \\ ${ }^{2}$ Sobolev Institute of Geology and Mineralogy and \\ Novosibirsk State University, Novosibirsk, Russia \\ *Corresponding author: alexanderellas@yahoo.com
}

\begin{abstract}
This study aims to help non-expert geologists in locating, classifying and analyzing lamprophyres, the exotic and complex rocks. The process includes three basic steps, a macroscopic study of the formation, petrographic microscopy and lastly whole-rock and trace element analyses of the samples. Fourteen Greek lamprophyric rocks with distinct characteristics were used. Conventional lamprophyres were considered along with rarer alkali minettes, meta-lamprophyres, lamproschists, appinites and para-lamproites.
\end{abstract}

Keywords: lamprophyric rocks, characterization, intelligibility, Greek islands, Macedonia

\section{Introduction}

The term lamprophyre, created by the German geologist Wilhelm von Gumbel, comes from the Greek word "lampros" which means glistening. Lamprophyres are uncommon mesocratic to holomelanocratic porphyritic hypabyssal rocks that contain only mafic phenocrysts (micas, amphiboles and lesser clinopyroxenes). Any feldspars, foids or quartz are constrained to the groundmass. Several igneous petrologists have, through the years, classified lamprophyric rocks (see Wimmenauer 1973; Streckeisen 1978; Le Maitre 1989; Chonghe 1991; Rock 1991; Woolley et al 1996; Le Maitre 2002; Tappe et al. 2005; Le Bas 2007; Krmíček, Krmíčková 2010; Mathieau et al. 2018). Today, the accepted lamprophyre nomenclature includes the calc-alkaline minette, kersantite, vogesite, spessartite and the alkaline camptonite, sannaite, monchiquite (Le Maitre 2002). Furthermore ultramafic lamprophyres such as alnöite, aillikite and damtjernite were later introduced (Tappe et al. 2005). Lamprophyric rocks also include alkali minettes (lampyrites of Krmíček et al. 2020), meta-lamprophyres, lam- proschists, appinites (sensu Rock 1991), para-lamproites (sensu Mitchell 2020) or lamproitoids and many local and obsolete varieties. These petrological terms are not IUGS accepted but are included since they are used by several igneous and exploration petrologists.

\section{Geological setting}

Greek lamprophyric rocks were used as a case study. The samples studied are from the following geological formations:

GL 7 and GL 8- Chortiatis magmatic suite in the Circum-Rhodope belt,

GL 10 and GL 11- Arnea A-type granitoid in the Serbo-Macedonian massif,

GL 12- Osiou Gregoriou granitoid in the Serbo-Macedonian massif,

GL 22- Kavala granitoid in the Rhodope massif,

GL 26- Agios Eustratios agglomerates in the Pelagonian zone,

GL 27 and GL28- Limnos molasse in the Circum-Rhodope belt, 


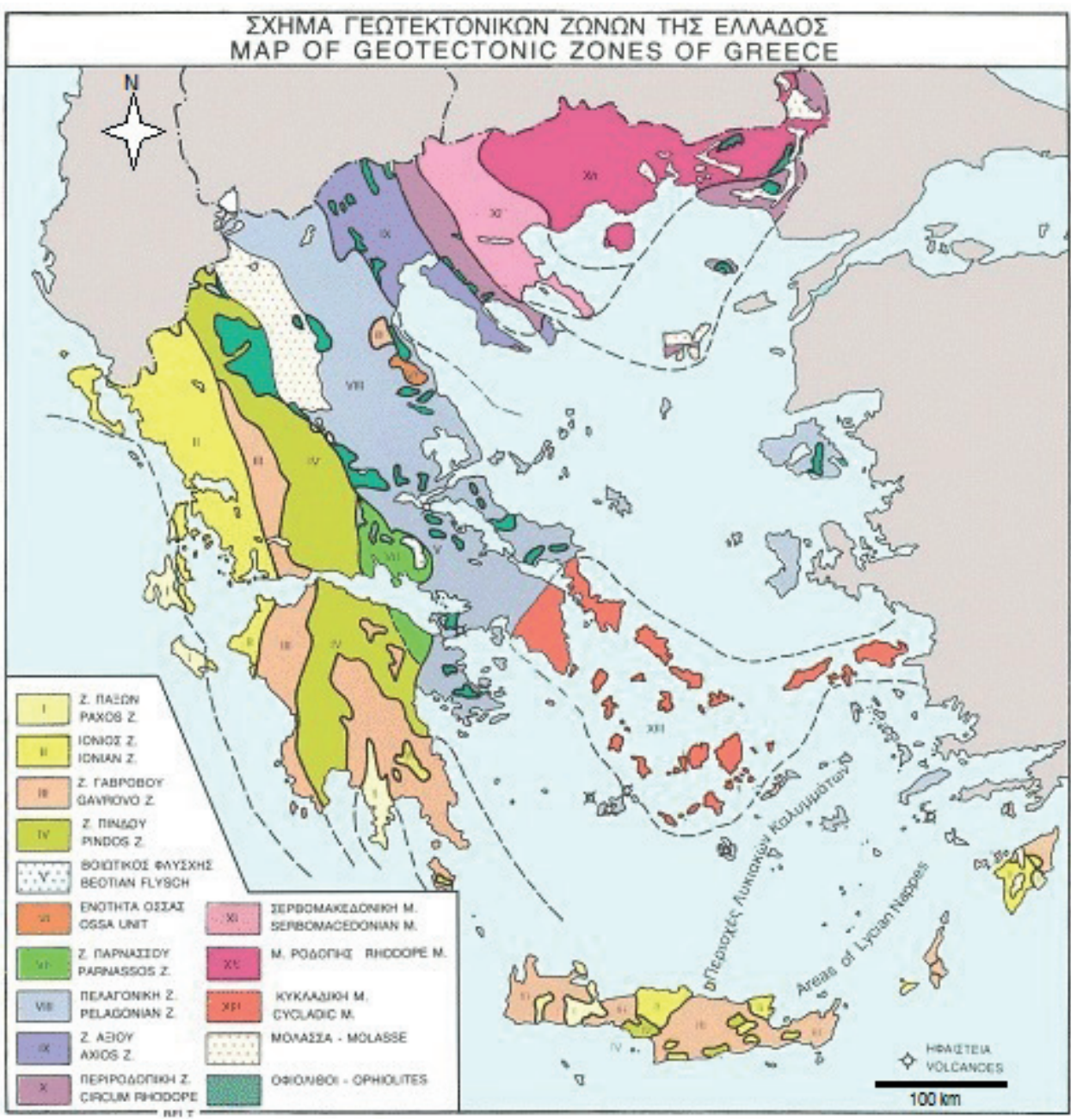

Figure 1. The geotectonic map of Greece with isopic zones (from E.A.G.M.E.). scope to more demanding geochemical analyses of major and trace elements in the whole rock sample. We propose a set of indicators under each of the three steps that will help a non-expert to recognize and classify the lamprophyric rocks.

\section{Discussion}

The three steps, including their sub-steps, are the following:

A. Field relationships and macroscopic characterization of the samples:

a. Define GPS coordinates that can be cross-checked with geological map. In case there are no GPS coordinates in bibliography use the toponyms in topographic maps;

b. Check and define rock associations. Calc-alkaline lamprophyres are generally associated with granitoids, alkaline lamprophyres with nepheline syenites and ultramafic lamprophyres with carbonatites;

c. Note that calc-alkaline lam-

GL 33- los basement augengneiss in the Attic-Cycladic complex.

The other four analyses are from the Osiou Gregoriou granitoid in Agion Oros (Serbo-Macedonian massif), the Mount Dikeos granitoid in Kos (Pelagonian zone), the Samothraki granitoid (Circum-Rhodope belt) and the Limnos shoshonitic volcanics (Circum-Rhodope belt). See Figure 1 from E.A.G.M.E. ((H)ellenic Authority for Geological and Mineral Exploration).

\section{Sample choice and methods}

The GL samples are from three different fieldtrips. The thin sections were prepared in the Matej Bel University in Banská Bystrica, Slovakia. They were examined microscopically in E.A.G.M.E. The rest of the samples are from bibliography. The studied samples were chosen since they are representative of Greek lamprophyres.

For the detection and classification of the various lamprophyric rocks three simple steps are recommended. These three steps (field relationships \& macroscopic characterization of samples, petrography and geochemistry) were chosen in that order, from an easy general examination of hand specimen through more detailed petrographical observations under an optical micro- prophyres are commonly located at the perimeter of the granitoid or cut the nearby country rocks;

d. Check for any Mafic Microgranular Enclaves since they have been frequently associated with lamprophyres;

e. Point out in the field any rocks that appear in the form of small volume mafic dikes (see Fig. 2), sills, minor lava flows or volcanic pipes;

f. By definition lamprophyric rocks are porphyritic and contain only mafic phenocrysts/macrocrysts/ megacrysts/oikocrysts;

g. Observe any typical globular structures like ocelli.

B. Petrography:

a. Check that there are no sparse felsic microphenocrysts (i.e. the rock is not a semi-lamprophyre). Appinites and meta-lamprophyres have a different texture;

b. Confirm that mafic phenocrysts include micas (see Fig. 3) and/or amphiboles and/or to a lesser extent clinopyroxene. Olivine phenocrysts are not characteristic of calc-alkaline lamprophyric rocks (see Rock 1984). Orthopyroxene is also very rare as a phenocryst and is found in only a few Bohemian (Krmíček et al. 2020) and Peruvian rocks (Carlier et al. 1996). Picritic rocks are excluded by the IUGS (Woolley et al. 1996); 


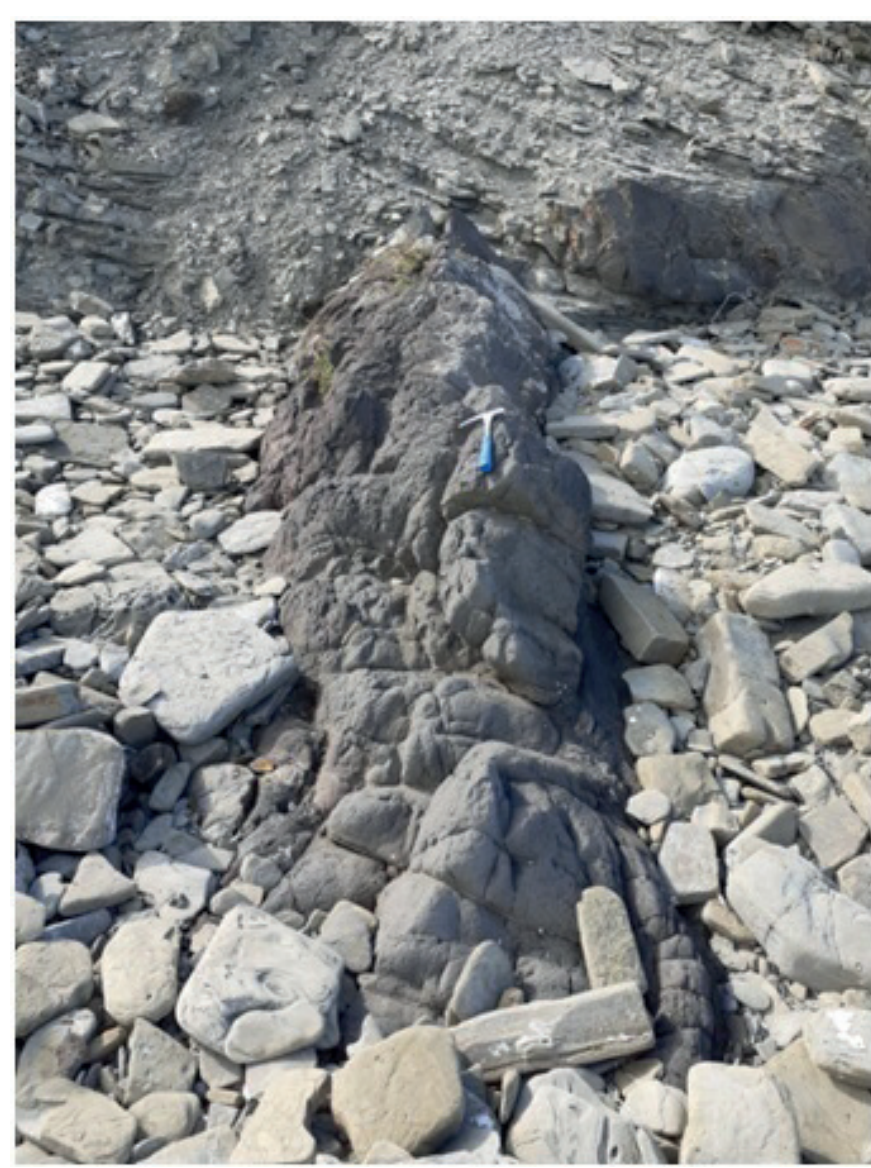

Figure 2. A lamprophyric dike (para-lamproite) intruding the molasse sediments at Agia Sotira in Limnos island.

c. Remember that leucocratic minerals such as plagioclase, alkali feldspar, foids and quartz are confined to the groundmass;

d. Note that lamprophyric rocks, with the exception of ultramafic lamprophyres, do not contain any groundmass olivine;

e. Define conventional lamprophyres (Le Maitre 2002, Tappe et al. 2005) with the help of the following mafic and felsic phases (see Table 1, first five are phenocrysts and the rest groundmass);

$\mathrm{f}$. Be aware that there are more unusual lamprophyric rocks which are defined as follows:
- Pyroxene lamprophyres: lamprophyres with exclusively clinopyroxene phenocrysts (see Fig. 3);

- Alkali minettes: ultrapotassic phlogopite minettes (Kamvisis 2010);

- Meta-lamprophyres: metamorphosed lamprophyres commonly containing large amphibole and small garnet crystals (see Fig. 3). Generally retain the initial lamprophyre chemistry (Perring et al. 1989). However if metamorphism is very progressive, the rock may lose water and fluids;

- Lamproschists: schistose lamprophyres with brown biotite and green hornblende (see Fig. 3). They generally retain initial chemistry (Perring et al. 1989);

- Appinites: It is a textural term. These are plutonic vogesites and spessartites (Rock 1991) with visible large amphibole crystals. They frequently appear as breccia pipes and are associated with conventional lamprophyres (e.g. in Agion Oros), see Fig. 3;

- Para-lamproites: lamproite-like lamprophyric rocks that cannot be characterized as bona fide lamproites;

g. Note that zeolites may appear as primary phases;

h. Check for ocelli. They are commonly detected under the microscope.

C. Geochemistry:

a. Observe the $\mathrm{SiO}_{2}$ content since the rocks are silica undersaturated having an ultrabasic to intermediate composition (on the TAS diagram the rocks occupy a wide area, see Fig. 4). Lamprophyres normally contain higher levels of $\mathrm{K}_{2} \mathrm{O}, \mathrm{Na}_{2} \mathrm{O}, \mathrm{P}_{2} \mathrm{O}_{5}$ and $\mathrm{Ba}$ (Le Maitre 2002) than conventional rocks with similar mineralogy. Note however, that $\mathrm{K}_{2} \mathrm{O}$ and $\mathrm{Na}_{2} \mathrm{O}$ are sometimes affected by alteration and metamorphism (e.g. secondary $\mathrm{K}_{2} \mathrm{O}$ enrichment in altered rocks). Also, they generally contain more Sr, Rb, Zr, Th (Rock 1987);

b. Distinguish calc-alkaline lamprophyres from ultramafic and alkaline lamprophyres with the use of $\mathrm{K}_{2} \mathrm{O}-\mathrm{SiO}_{2}$ diagram from Rock 1987 (see Fig. 4). Most Greek lamprophyric rocks fall in the calc-alkaline field. This dia-

Table 1. Necessary mineral phases of conventional calc-alkaline, alkaline and ultramafic lamprophyres.

\begin{tabular}{|c|c|c|c|c|c|c|c|c|c|c|}
\hline & biotite & hornblende & kaersutite & olivine & phlogopite & plagioclase & alk.feldspar & foid & melilite. & carbonate \\
\hline minette & yes & no & no & no & no & no & yes & no & no & no \\
\hline kersantite & yes & no & no & no & no & yes & no & no & no & no \\
\hline vogesite & no & yes & no & no & no & no & yes & no & no & no \\
\hline spessartite & no & yes & no & no & no & yes & no & no & no & no \\
\hline camptonite & no & no & yes & no & no & yes & no & no & no & no \\
\hline sannaite & no & no & yes & no & no & no & yes & no & no & no \\
\hline monchiquite & no & no & yes & no & no & no & no & yes & no & no \\
\hline alnöite & no & no & no & yes & yes & no & no & no & yes & no \\
\hline aillikite & no & no & no & yes & yes & no & no & no & no & yes \\
\hline damtjernite & no & no & no & yes & yes & no & yes & yes & no & no \\
\hline
\end{tabular}




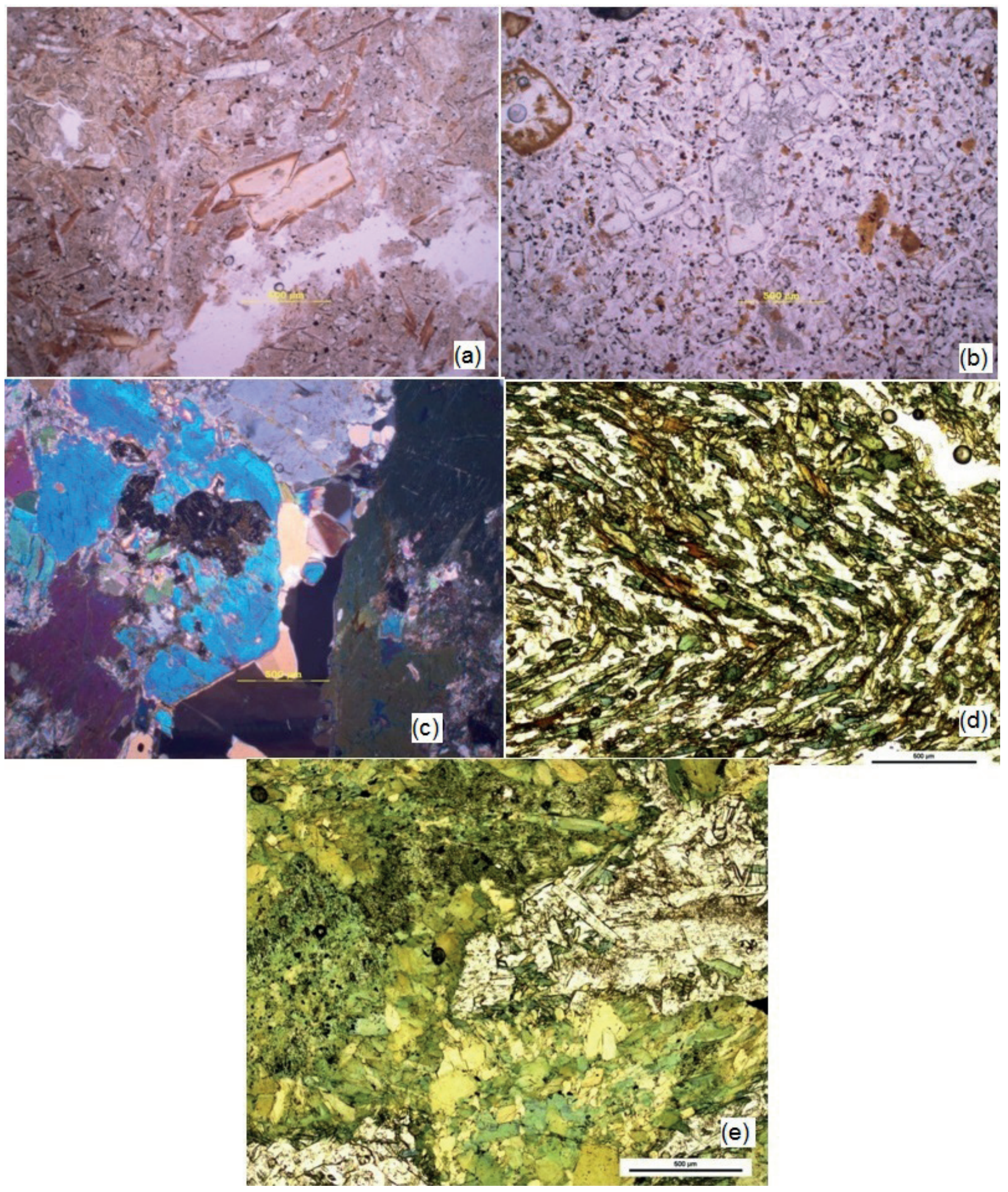

Figure 3. (a) A typical mica-phyric lamprophyric rock from Limnos island in plane polarized light (ppl) under the optical microscope, (b) A pyroxene lamprophyre from Agios Eustratios island with augite phenocrysts in ppl, (c) A meta-lamprophyre from los island in crossed polarized light (xpl), (d) A lamproschist from the Arnea A-type granitoid in Macedonia, northern Greece in ppl, (e) An appinite from the Osiou Gregoriou granitoid in Agion Oros in ppl.

gram is also useful for lamprophyric rocks from different geological backgrounds (e.g. Rao et al. 2020);

c. Focus on most primary lamprophyres which are the most petrologically useful (i.e. not crustally contaminated or crystal fractionated). These should obey (accord- ing to Rock 1991) the following criteria based on Mg\# and compatible elements:

- Mg\#=65-80. According to Mg\#, eight out of fourteen samples in this study can be considered as primary. Higher Mg\#'s could indicate crystal accumu- 

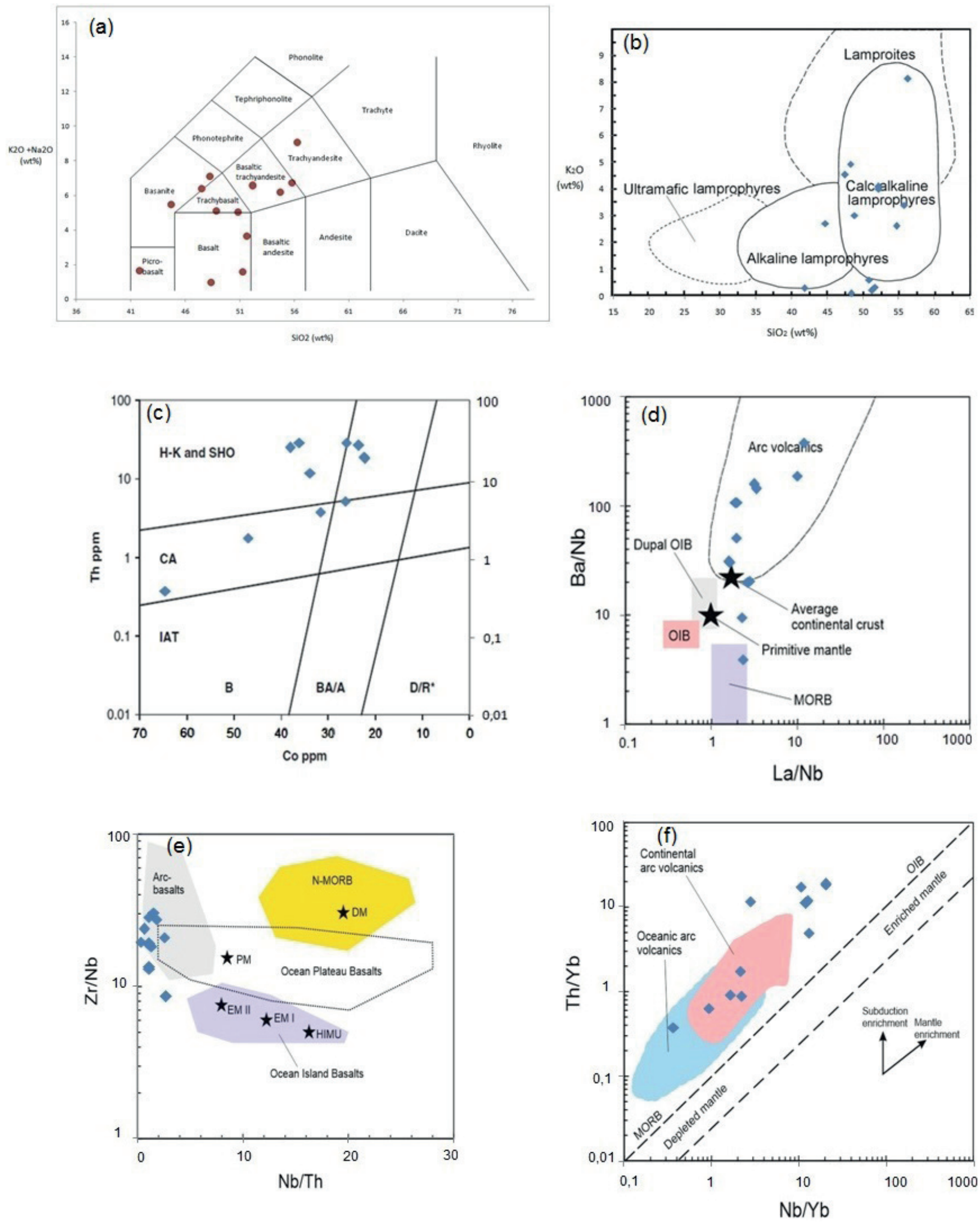

Figure 4. (a) TAS, (b) $\mathrm{K}_{2} \mathrm{O}-\mathrm{SiO}_{2}$ after Rock (1987), (c) Co vs Th after Hastie et al. (2007), (d) La/Nb vs Ba/Nb, (e) Nb/Th vs Zr/Nb and (f) $\mathrm{Nb} / \mathrm{Yb}$ vs $\mathrm{Th} / \mathrm{Yb}$ diagrams with the Greek lamprophyric rocks.

lation (Pe-Piper pers. communication). However, in sample GL8 (Mg\#=82) this is not the case since in subduction related environments like the Chortiatis magmatic suite (Bonev pers. communication) hornblende is not a cumulus phase (Gill 2011).

- $\mathrm{Sc}=15-30 \mathrm{ppm}$

- $\mathrm{Cr}=200-500 \mathrm{ppm}$ 
Table 2. Whole rock/trace elements analyses of Greek lamprophyres (for locations see section 2). First four Georgiades (1938), Soder (2017), Christofides et al. (2000), Djiba (2018). Others, this study (BV). Major elements in wt.\%, trace elements in ppm, \#Mg in \%.

\begin{tabular}{|c|c|c|c|c|c|c|c|c|c|c|c|c|c|c|}
\hline Sample & Agion Oros & KL66 & PA05 & lem21 & GL7 & GL8 & GL10 & GL11 & GL12 & GL22 & GL26 & GL27 & GL28 & GL33 \\
\hline $\mathrm{SiO}_{2}$ & 48.82 & 44.7 & 56.27 & 55.76 & 51.27 & 48.38 & 41.78 & 50.85 & 51.66 & 54.70 & 52.20 & 48.23 & 47.48 & 52.20 \\
\hline $\mathrm{Al}_{2} \mathrm{O}_{3}$ & 14.69 & 14.60 & 11.70 & 14.63 & 13.33 & 11.28 & 13.45 & 13.90 & 13.09 & 15.90 & 13.98 & 11.23 & 10.87 & 14.11 \\
\hline $\mathrm{Fe}_{2} \mathrm{O}_{3}$ & 3.60 & 8.11 & 5.64 & 5.67 & 8.68 & 7.98 & 18.21 & 11.93 & 12.92 & 7.12 & 6.96 & 7.01 & 6.99 & 7.31 \\
\hline $\mathrm{MgO}$ & 10.88 & 9.24 & 9.42 & 3.63 & 13.28 & 17.13 & 8.04 & 5.11 & 3.03 & 5.35 & 5.51 & 9.90 & 10.97 & 5.53 \\
\hline $\mathrm{CaO}$ & 8.05 & 10.40 & 5.21 & 4.49 & 6.10 & 7.00 & 12.54 & 8.61 & 7.37 & 6.25 & 8.25 & 5.89 & 6.05 & 8.36 \\
\hline $\mathrm{Na}_{2} \mathrm{O}$ & 2.08 & 2.75 & 0.94 & 3.32 & 1.37 & 0.86 & 1.35 & 4.41 & 3.32 & 3.58 & 2.49 & 2.17 & 1.86 & 2.54 \\
\hline $\mathrm{K}_{2} \mathrm{O}$ & 3.01 & 2.71 & 8.11 & 3.39 & 0.21 & 0.10 & 0.29 & 0.61 & 0.32 & 2.61 & 4.09 & 4.93 & 4.53 & 4.00 \\
\hline $\mathrm{TiO}_{2}$ & 1.39 & 1.05 & 1.12 & 0.66 & 0.33 & 0.23 & 2.32 & 2.10 & 3.14 & 0.69 & 1.06 & 1.60 & 1.56 & 1.09 \\
\hline $\mathrm{P}_{2} \mathrm{O}_{5}$ & - & 1.18 & 1.06 & 0.31 & 0.05 & 0.03 & 0.02 & 0.25 & 0.52 & 0.42 & 0.96 & 1.02 & 0.98 & 1.00 \\
\hline $\mathrm{MnO}$ & n.a. & 0.14 & 0.24 & 0.10 & 0.14 & 0.15 & 0.18 & 0.20 & 0.19 & 0.15 & 0.08 & 0.08 & 0.10 & 0.08 \\
\hline $\mathrm{Cr}$ & n.a. & 287 & n.a. & n.a. & 1020 & 1471 & 48 & 55 & 34 & 62 & 383 & 656 & 643 & 404 \\
\hline $\mathrm{Ba}$ & n.a. & 1780 & 2284 & 3252 & 49 & 12 & 43 & 72 & 56 & 1494 & 2515 & 1016 & 971 & 2348 \\
\hline $\mathrm{Ni}$ & n.a. & 111 & n.a. & n.a. & 331 & 679 & $<20$ & 21 & $<20$ & 24 & 78 & 194 & 427 & 78 \\
\hline Sc & n.a. & 41 & 18 & n.a. & 33 & 33 & 56 & 42 & 41 & 26 & 29 & 22 & 21 & 30 \\
\hline LOI & n.a. & 3.94 & n.a. & 5.28 & 5.00 & 6.50 & 1.60 & 1.80 & 4.20 & 2.70 & 3.80 & 7.40 & 8.10 & 3.20 \\
\hline Sum & 92.52 & 98.68 & 99.47 & 97.14 & 99.62 & 99.49 & 99.6 & 99.57 & 99.57 & 99.32 & 99.3 & 99.38 & 99.39 & 99.34 \\
\hline Mg\# & 78 & 71 & 80 & 60 & 76 & 82 & 47 & 47 & 33 & 64 & 65 & 75 & 77 & 64 \\
\hline $\mathrm{Be}$ & n.a. & n.a. & n.a. & 7 & $<1$ & $<1$ & 1 & 3 & 4 & 4 & 4 & 5 & 6 & 5 \\
\hline Co & n.a. & 34 & n.a. & 36.3 & 47.3 & 64.9 & 82.3 & 31.8 & 26.5 & 26.3 & 22.6 & 23.6 & 38.2 & 22.3 \\
\hline Cs & n.a. & 3 & n.a. & 7 & $<0.1$ & $<0.1$ & $<0.1$ & 0.8 & $<0.1$ & 12.2 & 2.1 & 2.5 & 1.9 & 2.1 \\
\hline Ga & n.a. & n.a. & n.a. & 15.7 & 13.4 & 10.4 & 17.5 & 19.4 & 25.0 & 18.9 & 15.5 & 15.9 & 15.7 & 15.6 \\
\hline $\mathrm{Hf}$ & n.a. & 7.5 & n.a. & 13.3 & 1.2 & 0.6 & 0.4 & 5.1 & 7.3 & 4.0 & 8.7 & 17.1 & 15.8 & 8.1 \\
\hline $\mathrm{Nb}$ & n.a. & 35 & 6 & 20.6 & 2.4 & 0.6 & 0.3 & 7.5 & 14.3 & 8.0 & 23.5 & 33.5 & 31.5 & 21.9 \\
\hline $\mathrm{Rb}$ & n.a. & 72 & 389 & 222.9 & 3.1 & 1.2 & 3.8 & 15.6 & 5.7 & 118.7 & 165.5 & 213.1 & 196.2 & 167.4 \\
\hline Sn & n.a. & n.a. & n.a. & 4 & $<1$ & $<1$ & $<1$ & 3 & 5 & 4 & 3 & 3 & 3 & 3 \\
\hline $\mathrm{Sr}$ & n.a. & 1410 & 557 & 1270 & 68.7 & 19.1 & 170.5 & 120.5 & 170.2 & 1684.8 & 885.1 & 637.3 & 588.9 & 825.0 \\
\hline $\mathrm{Ta}$ & n.a. & 1.6 & n.a. & 1.6 & 0.2 & $<0.1$ & $<0.1$ & 0.6 & 0.9 & 0.4 & 0.8 & 1.6 & 1.5 & 0.9 \\
\hline Th & n.a. & 13 & n.a. & 32.5 & 1.9 & 0.4 & 0.3 & 4.1 & 5.7 & 32.3 & 21.0 & 29.7 & 28.0 & 20.2 \\
\hline$U$ & n.a. & 2.9 & n.a. & 8.1 & 0.6 & 0.6 & 0.6 & 1.5 & 3.1 & 13.6 & 3.2 & 5.3 & 6.2 & 3.1 \\
\hline $\mathrm{V}$ & n.a. & 231 & 49 & 134 & 200 & 156 & 1126 & 326 & 377 & 175 & 183 & 139 & 131 & 198 \\
\hline W & n.a. & n.a. & n.a. & 87.8 & 0.5 & $<0.5$ & $<0.5$ & 1.3 & 1.0 & 1.9 & 1.8 & 2.2 & 1.4 & 4.1 \\
\hline $\mathrm{Zr}$ & n.a. & 299 & 846 & 487.1 & 43.8 & 18.3 & 8.5 & 205.7 & 296.7 & 154.8 & 312.3 & 635.3 & 593.4 & 285.5 \\
\hline$Y$ & n.a. & 30 & 47 & 21.2 & 10.7 & 5.8 & 8.4 & 48.5 & 73.5 & 29.7 & 20.5 & 20.9 & 19.4 & 18.6 \\
\hline La & n.a. & 69 & 72 & 65.1 & 6.7 & 1.6 & 1.0 & 17.0 & 33.4 & 80.2 & 45.2 & 54.9 & 49.8 & 43.5 \\
\hline $\mathrm{Ce}$ & n.a. & 153 & 151 & 135 & 13.3 & 3.4 & 2.5 & 41.0 & 60.5 & 162.1 & 90.1 & 121.7 & 118.9 & 87.3 \\
\hline $\mathrm{Pr}$ & n.a. & 18 & n.a. & 16.18 & 1.60 & 0.45 & 0.38 & 5.43 & 8.96 & 20.05 & 11.77 & 16.55 & 15.49 & 10.70 \\
\hline $\mathrm{Nd}$ & n.a. & 75 & 84 & 63.9 & 6.3 & 2.1 & 1.9 & 23.6 & 39.2 & 77.0 & 45.2 & 66.1 & 62.3 & 41.4 \\
\hline $\mathrm{Sm}$ & n.a. & 13 & n.a. & 10.39 & 1.40 & 0.59 & 0.84 & 6.50 & 9.68 & 13.07 & 7.35 & 10.45 & 9.72 & 6.97 \\
\hline $\mathrm{Eu}$ & n.a. & 3.4 & n.a. & 2.19 & 0.36 & 0.19 & 0.43 & 2.00 & 3.08 & 2.87 & 1.76 & 2.32 & 2.20 & 1.71 \\
\hline $\mathrm{Gd}$ & n.a. & 9.1 & n.a. & 7.02 & 1.67 & 0.83 & 1.31 & 8.04 & 12.40 & 8.79 & 5.62 & 6.96 & 6.40 & 5.19 \\
\hline $\mathrm{Tb}$ & n.a. & 1.1 & n.a. & 0.87 & 0.29 & 0.15 & 0.24 & 1.36 & 2.09 & 1.11 & 0.71 & 0.81 & 0.78 & 0.66 \\
\hline Dy & n.a. & 6 & n.a. & 4.49 & 1.81 & 1.05 & 1.59 & 8.49 & 12.66 & 5.85 & 3.96 & 4.19 & 3.88 & 3.46 \\
\hline Ho & n.a. & 1.08 & n.a. & 0.8 & 0.41 & 0.21 & 0.33 & 1.79 & 2.67 & 1.07 & 0.74 & 0.71 & 0.70 & 0.69 \\
\hline $\mathrm{Er}$ & n.a. & 2.8 & n.a. & 2.14 & 1.17 & 0.65 & 0.97 & 5.18 & 7.79 & 3.00 & 2.10 & 1.87 & 1.82 & 1.86 \\
\hline $\mathrm{Tm}$ & n.a. & 0.37 & n.a. & 0.28 & 0.17 & 0.11 & 0.13 & 0.72 & 1.08 & 0.41 & 0.27 & 0.27 & 0.24 & 0.26 \\
\hline $\mathrm{Yb}$ & n.a. & 2.7 & n.a. & 1.92 & 1.11 & 0.64 & 0.81 & 4.52 & 6.49 & 2.85 & 1.94 & 1.66 & 1.54 & 1.72 \\
\hline Lu & n.a. & 0.38 & n.a. & 0.27 & 0.16 & 0.10 & 0.12 & 0.66 & 1.03 & 0.42 & 0.27 & 0.25 & 0.24 & 0.25 \\
\hline
\end{tabular}


- $\mathrm{Co}=25-80 \mathrm{ppm}$

- $\mathrm{Ni}=90-700 \mathrm{ppm}$

A more useful diagram, compared to TAS is the Co vs Th based on immobile trace elements (Pandey pers. communication). Most Greek lamprophyric rocks fall in the high-K to shoshonitic (i.e. subduction) field (see Fig. 4); d. Use slightly more complex diagrams which can point to the initial magma source. These are the $\mathrm{La} / \mathrm{Nb}$ vs Ba/ $\mathrm{Nb}$, the $\mathrm{Nb} / \mathrm{Th}$ vs $\mathrm{Zr} / \mathrm{Nb}$ and the $\mathrm{Nb} / \mathrm{Yb}$ vs Th/Yb. In the case of Greek lamprophyric rocks they appear to be of continental arc basalt origin (see Fig. 4);

e. Note that alkali minettes and para-lamproites are primitive rocks that have many lamproitic geochemical characteristics such as $\mathrm{Al}_{2} \mathrm{O}_{3}<12, \mathrm{TiO}_{2}>1, \mathrm{Fe}_{2} \mathrm{O}_{3}<10$, $\mathrm{MgO}>5, \mathrm{Mg \#}>70$ (in Table 2, 80 and 77 respectively), $\mathrm{MgO}>\mathrm{CaO}, \mathrm{CaO}<10, \mathrm{~K}_{2} \mathrm{O}>3$ (Mitchell 2020), $\mathrm{K}_{2} \mathrm{O} / \mathrm{Na}_{2} \mathrm{O}>2$ (ultrapotassic sensu Foley et al. 1987), $\mathrm{Cr}>500, \mathrm{Ni}>300$ (Vladykin 2008). Alkali minettes are generally associated with granitoids and para-lamproites with shoshonites. The GL28 sample from Agia Sotira in Limnos is a para-lamproite (or possibly a Mediterranean lamproite). It is the most primitive magma on the island (see Pe-Piper et al. 2009). A bi-folded procedure for the formation of para-lamproite like cocite, with an earlier modification of Metasomatized Lithospheric Mantle (MLM) followed by decomposition of phlogopitic residue, might explain the rarity of para-lamproites (Krmíček et al. 2014). Note that a potassic character increase with increasing depth of subduction magmatism could eventually lead to lamproite magmas (Mitchell, Bergman 1991). A possible gradation among these exotic volatile-rich MLM rocks would be as follows:

Anorogenic lamproites $\rightarrow$ Mediterranean lamproites $\rightarrow$ para-lamproites (e.g. cocite) $\rightarrow$ alkali minettes $\rightarrow$ minettes (C. Rao pers. communication).

Only the two end members (anorogenic lamproites, minettes) are very distinct rocks that vary considerably; f. Remember that most lamprophyric rocks have a lithospheric mantle origin (MLM). Lamprophyres form at depths of $60-190 \mathrm{~km}$ within the mantle (O' Neill, Wyman 2006). However, asthenospheric lamprophyric rocks also exist (e.g. the crustally contaminated GL10 in Table 2). These compared with the lithospheric rocks have $\mathrm{TiO}_{2}>2$ and $\mathrm{Ti} / \mathrm{Y}>370$ (Ma et al. 2014). Sample GL10 differs greatly from all other studied rocks. This sample shows also a uniquely high enrichment in V (1126 ppm) and Sc (56 ppm) compared with other lamprophyric rocks from around the world (Rock 1987; Scarrow et al. 2008). Lamprophyres with an asthenospheric imprint have additionally been found in the mount Dikeos granitoid of Kos island (Soder 2017);

g. Be aware that the features of the REE distribution correlate with the content of $\mathrm{K}$. Spidergrams should generally be avoided in the case of lamprophyric rocks since they were devised for simple rocks like oceanic basalts. They are not devised for MLM rocks where complex processes such as autometasomatism take place (Mitchell pers. communication).

\section{Final remarks}

Although lamprophyric rocks appear as a serious petrological problem since the $19^{\text {th }}$ century, macroscopic, petrographic and geochemical observations are indeed very useful for the identification of these complex rocks. With the three basic steps mentioned above a non-expert geologist could locate, classify and analyze genetically distinct lamprophyric types such as calc-alkaline, alkaline and ultramafic lamprophyres, rare alkali minettes, metamorphosed lamprophyres, appinitic gabbroids and lamproite-like para-lamproites. The Greek Metasomatized Lithospheric Mantle rocks are generally primitive and have a subduction signature. The original source magmas seem to have been continental island arc basalts.

\section{Acknowledgements}

Many thanks to God for enabling us complete this document. We also thank Prof. Jan Spisiak (Matej Bel University) for the thin sections and the analyses. Lastly, we thank A. Hatziapostolou (microscopy), A. Pandey (diagrams), G. Pe-Piper (comments), A. Cooper (comments), R. Mitchell, Mr. Thanasis, G. Christofides, Fr. Kallistos, B. Murphy, P. Voudouris, E. Zananiri, A. Photiades, D. Tarenides, S. Bergman, C. Rao, S. Conticelli, N. Bonev and the two reviewers for their time, help and useful suggestions.

\section{References}

Carlier, G., Lorand, J. P., Bonhomme, M. \& Carlotto, V. (1996). A reappraisal of the Cenozoic inner arc magmatism in southern Peru: consequences for the evolution of the Central Andes for the past $50 \mathrm{Ma}$. Third ISAG, (pp. 551554). St. Malo, France.

Chonghe, L. F. S. X. Z. (1991). A suggestion on classification of lamprophyres. Geological Science and Technology Information, S1.

Christofides, G., Eleftheriadis, G., Esson, J., Soldatos, T., Koroneos, A., \& Brocker, M. (2000). The evolution of the Samothraki granitic pluton (N. Aegean Sea, Greece). Geochronology, chemical and isotopic constraints for AFC modeling. Proceedings of the Third International Conference on the Geology of the Eastern Mediterranean (pp. 193-209). Nicosia, Cyprus.

Djiba, A. (2018). Porphyrische Cu-Mo-Au-Re und epithermale Au-Ag-Te Vererzungen der Insel Limnos, nordöstliche Ägäis, Griechenland: Mineralogie-Mineralchemie der hydrothermalen Alterationen und damit verbundene Vererzungen. Doctoral dissertation, Universität Hamburg, Germany. 
Foley, S., Venturelli, G., Green, D. H., \& Toscani, L. (1987). The ultrapotassic rocks: characteristics, classification, and constraints for petrogenetic models. Earth-Science Reviews, 24(2), 81-134.

Georgiades, A. N. (1938). La Kersantite du Couvent de St. Gregoire, dans le Mont Athos. Praktika Akademias Athenon, 13, 487-491.

Gill, R. (2011). Igneous rocks and processes: a practical guide. Oxford: John Wiley \& Sons.

Hastie, A. R., Kerr, A. C., Pearce, J. A., \& Mitchell, S. F. (2007). Classification of altered volcanic island arc rocks using immobile trace elements: development of the Th-Co discrimination diagram. Journal of Petrology, 48(12), 2341-2357. DOI:10.1093/petrology/egm062

Kamvisis, I.-N. (2010). Occurrences of lamprophyric rocks in Greece. Neues Jahrbuch fur Mineralogie Abhandlungen 187(2), 225-234. DOI: 10.1127/0077-7757/2010/0173

Krmíček, L., \& Krmíčková, M. (2010). Recent view on a definition and classification of lamprophyres. MineralogiaSpecial Papers, 37, 47-48.

Krmíček, L., Halavinova, M., Romer, R. L., Galiova, M. V., \& Vaculovic, T. (2014). Phlogopite/matrix, cpx/matrix and $\mathrm{cpx} /$ phlogopite trace-element partitioning in a calc-alkaline lamprophyre: new constrains from the Krizanovice minette dyke (Bohemian Massif). Journal of Geosciences, 59(1), 87-96. DOI: 10.3190/jgeosci.160

Krmíček, L., Romer, R. L., Timmerman, M. J., Ulrych, J., Glodny, J., Přichystal, A., \& Sudo, M. (2020). Long-lasting (65 $\mathrm{Ma})$ regionally contrasting late-to post-orogenic Variscan mantle-derived potassic magmatism in the Bohemian Massif. Journal of Petrology, 61(7), egaa072. DOI:10.1093/petrology/egaa072

Le Bas, M., (2007). Igneous rock classification revisited 4: Lamprophyres. Geology Today, 23, 167-168.

Le Maitre, R. W. (1989). A classification of igneous rocks and glossary of terms. Recommendations of the IUGS Subcommission on the Systematics of Igneous rocks. London: Blackwell Scientific Publications.

Le Maitre, R. W. (2002). Igneous rocks. a Classification and Glossary of Terms. Recommendations of the IUGS Subcommission on the Systematics of Igneous Rocks. (2nd Ed.). Cambridge: Cambridge University Press.

Ma, L., Jiang, S. Y., Hofmann, A. W., Dai, B. Z., Hou, M. L., Zhao, K. D., Chen, L. H., Li, J. W., \& Jiang, Y. H. (2014). Lithospheric and asthenospheric sources of lamprophyres in the Jiaodong Peninsula: a consequence of rapid lithospheric thinning beneath the North China Craton?. Geochimica et Cosmochimica Acta, 124, 250271. DOI:10.1016/j.gca.2013.09.035

Mathieu, L., Bouchard, É., Guay, F., Liénard, A., Pilote, P., \& Goutier, J. (2018). Criteria for the recognition of Archean calc-alkaline lamprophyres: examples from the Abitibi Subprovince. Canadian Journal of Earth Sciences, 55(2), 188-205. DOI:10.1139/cjes-2017-0152

Mitchell, R. H., \& Bergman, S. C. (1991). Petrology of Lamproites. New York: Plenum Press.

Mitchell, R. H. (2020). Igneous Rock Associations 26. Lamproites, Exotic Potassic Alkaline Rocks: A Review of their Nomenclature, Characterization and Origins. Geoscience Canada: Journal of the Geological Association of Canada/Geoscience Canada: journal de l'Association Géologique du Canada, 47(3), 119-142. DOI: https:// doi.org/10.12789/geocanj.2020.47.162
O'Neill, C., \& Wyman, D. A. (2006). Geodynamic modelling of Late Archean subduction. Pressure temperature constraints from greenstone belt diamond deposits. In K. Benn, J.-C. Mareschal \& K. C. Condie (Eds.), Washington DC American Geophysical Union Geophysical Monograph Series 164 (pp. 177-188). Washington, D.C.: American Geophysical Union.

Pe-Piper, G., Piper, D. J. W., Koukouvelas, I., Dolansky, L. M., \& Kokkalas, S. (2009). Postorogenic shoshonitic rocks and their origin by melting underplated basalts: The Miocene of Limnos, Greece. Geological Society of America Bulletin, 121(1/2), 39-54. DOI: 10.1130/B26317.1

Perring, C. S., Rock, N. M., Golding, S. D., \& Roberts, D. E. (1989). Criteria for the recognition of metamorphosed or altered lamprophyres: a case study from the Archaean of Kambalda, Western Australia. Precambrian Research, 43(3), 215-237. DOI:10.1016/03019268(89)90057-0

Rao, N. C., Giri, R. K., Sharma, A., \& Pandey, A. (2020). Lamprophyres from the Indian shield: A review of their occurrence, petrology, tectonomagmatic significance and relationship with the Kimberlites and related rocks. $E p$ isodes Journal of International Geoscience, 43(1), 231248. DOI:10.18814/epiiugs/2020/020014

Rock, N. M. S. (1984). Nature and origin of calc-alkaline lamprophyres: minettes, vogesites, kersantites and spessartites. In Transactions of the Royal Society of Edinburgh, 74, 193-227. DOI:10.1017/S0263593300013663

Rock, N. M. S. (1987). The nature and origin of lamprophyres: an overview. In: J. G. Fitton, \& B. G. J. Upton, (Eds.), Alkaline Igneous Rocks, Special Publications, 30, (pp. 191-226). London: Geological Society of London DOI:10.1144/GSL.SP.1987.030.01.09

Rock, N. M. S. (1991). Lamprophyres. Glasgow: Blackie and Son Ltd.

Scarrow, J. H., Bea, F., Montero, P., \& Molina, J. F. (2008). Shoshonites, vaugnerites and potassic lamprophyres: similarities and differences between 'ultra'-high-K rocks. Earth and Environmental Science Transactions of the Royal Society of Edinburgh, 99(3-4), 159-175. DOI: 10.1017/S1755691009008032

Soder, C. (2017). Geochemistry and petrology of lamprophyres from the Hellenides and the European Variscides. Doctoral dissertation, University of Heidelberg, Heidelberg, Germany.

Streckeisen, A. (1978). IUGS Subcommission on the Systematics of Igneous Rocks. Classification and Nomenclature of Volcanic Rocks, Lamprophyres, Carbonatites and Melilite Rocks. Recommendations and Suggestions. Neues Jahrbuch fur Mineralogie Abhandlungen, 143, 1-14.

Tappe, S., Foley, S. F., Jenner, G. A., \& Kjarsgaard, B. A. (2005). Integrating ultramafic lamprophyres into the IUGS classification of igneous rocks: rationale and implications. Journal of Petrology, 46(9), 1893-1900. DOI:10.1093/petrology/egi039

Vladykin, N. V. (2008). Formation types of lamproite complexes-systematization and chemism. 9th International Kimberlite Conference, Frankfurt, Germany, Extended Abstract No. 9IKCA-00409.

Wimmenauer W., (1973). Lamprophyre, Semilamprophyre und anchibasaltische Ganggesteine. Fortschritte der Mineralogie, 51, 3-67. 
Woolley, A. R., Bergman, S. C., Edgar, A. D., Le Bas, M. J., Mitchell, R. H., Rock, N. M. S., \& Smith, B. H. S. (1996). Classification of lamprophyres, lamproites, kimberlites, and the kalsilitic, melilitic and leucitic rocks. Canadian Mineralogist, 34, 175-186.

Received: 25 June 2021

Accepted: 28 September 2021

Handling Editor: Jarosław Majka 